\title{
Aktivitas Antibakteri Ekstrak Etanol Daun Suruhan (Peperomia pellucida L. Kunth) Terhadap Bakteri Staphylococcus aureus
}

\section{Antimicrobial Activity of Ethanolic Extracts Suruhan (Peperomia pellucida L. Kunth) Leaves Against Staphylococcus aureus}

\author{
Isna Jati Asiyah, Destik Wulandari \\ Fakultas Farmasi, Universitas Setia Budi Surakarta \\ email: Isna jati@yahoo.co.id \\ (Diterima : 2019-04-20, disetujui : 2019-10-15)
}

\begin{abstract}
ABSTRAK
Bakteri Staphylococcus aureus adalah bakteri penyebab penyakit infeksi. Penyakit yang disebabkan oleh infeksi bakteri ini antara lain inflamasi payudara (mastitis), endocarditis, infeksi saluran pernafasan, serta infeksi pada kulit. Bakteri $S$. aureus dilaporkan mengalami resitensi terhadap aktivitas antibiotik golongan $\beta$-laktam, sehingga perlu alternatif penggunaan bahan alami berbahan dasar tumbuhan. Tumbuhan suruhan (Peperomia pellucida L. Kunth) memiliki kandungan senyawa aktif tanin dan flavonoid yang dapat berperan sebagai antimikroba. Penelitian ini bertujuan untuk mengetahui aktivitas antibakteri ekstrak daun suruhan (Peperomia pellucida L. Kunth) terhadap bakteri $S$. aureus.

Daun suruhan diekstraksi dengan cara maserasi menggunakan larutan etanol $70 \%$, selanjutnya dilakukan uji antibakteri dengan metode dilusi untuk mengetahui Konsentrasi Hambat Minimum (KHM) dan konsentrasi Bunuh Minimum (KBM). Ekstrak suruhan dibuat dalam 5 seri konsentrasi yaitu 100\%, $80 \%, 60 \%, 40 \%$, dan $20 \%$.

Hasil yang diperoleh menunjukkan nilai KHM tidak dapat ditentukan karena campuran antara ekstrak daun suruhan dan bakteri $S$. aureus sangat keruh. KBM yang diperoleh pada uji aktivitas antibakteri ekstrak daun suruhan terhadap bakteri $S$. aureus adalah $40 \%$. Aktivitas antibakteri pada daun suruhan dikarenakan adanya kandungan senyawa kimia berupa tanin dan flavonoid.
\end{abstract}

Kata Kunci : Antibakteri, Peperomia pellucida L. Kunth, Staphylococcus aureus, dilusi

\section{ABSTRACT}

Staphylococcus aureus causes infectious diseases include breast inflammation (mastitis), endocarditis, respiratory tract infections, and infections of the skin. Drug from natural resources needs because $\beta$-lactam group antibiotic activity had been resistance to $S$. aureus. The herb plants (Peperomia pellucida L. Kunth) has active tannins and flavonoids act as antimicrobials. This research aims to determine antibacterial activity of leaf extract (Peperomia pellucida L. Kunth) against $S$. aureus.

The leaf leaves were extracted by maceration using $70 \%$ ethanol solution, then an antibacterial test was carried out using the dilution method to determine the Minimum Inhibitory Concentration (MIC) and Minimum Bactericidal Concentration (MBC). Extracts was made in 5 series concentration: $100 \%, 80 \%, 60 \%, 40 \%$, and $20 \%$.

The results showed MIC value could not be determined because the mixture between the leaf extract and $S$. aureus bacteria was very cloudy. MBC obtained from the antibacterial activity test of leaf extract on S. aureus bacteria was $40 \%$. Antibacterial activity of suruhan leaves caused by tannin and flavonoid compound.

Keyword : Antibacterial, Peperomia pellucida L. Kunth, Staphylococcus aureus, dilution 


\section{PENDAHULUAN}

Bakteri Staphylococcus aureus adalah bakteri penyebab penyakit infeksi. Infeksi serius $S$. aureus dapat terjadi ketika sistem imun melemah yang disebabkan oleh perubahan hormon, penyakit, luka, penggunaan steroid atau obat lain yang mempengaruhi imunitas. Penyakit yang disebabkan oleh infeksi bakteri $S$ .aureus adalah inflamasi payudara (mastitis), endocarditis, infeksi saluran pernafasan seperti pneumonia, serta infeksi pada kulit berupa impetigo, folikulitis, dan abses (Conrad, 2010). Selain itu, $S$. aureus juga dapat menyebabkan terjadinya sindroma syok toksik dan keracunan makanan dengan gejala mual, muntah, diare (Conrad, 2010; Afifurrahman, 2014).

Pada umumnya, penderita infeksi bakteri $S$. aureus diberikan terapi berupa antibiotik. Era antibiotik ditandai dengan pemakaian penicillin pada tahun 1944 dan metisilin pada tahun 1950-an yang sangat manjur untuk mengobati infeksi $S$. aureus. Namun, keberhasilan terapi ini tidak dapat berlangsung lama karena kemudian muncul galur $S$. aureus resisten metisilin yang disebut MRSA (Yuwono, 2010). Methicillin-resistant Staphylococcus aureus merupakan strain $S$. aureus yang telah resisten terhadap aktivitas antibiotik golongan $\beta$ laktam (Afifurrahman, 2014).

Resistensi bakteri terhadap antibiotik dapat mengakibatkan lamanya waktu penyembuhan, meningkatkan resiko kematian, memperbanyak carrier di masyarakat, memperbanyak bakteri yang resisten, dan memperpanjang masa rawat inap di rumah sakit (Utami, 2012).

Dewasa ini perkembangan pengobatan telah mengarah kembali ke alam (back to nature) karena obat tradisional telah terbukti lebih aman dan tidak menimbulkan efek samping seperti halnya obat-obat kimia. Pemanfaatan tumbuh-tumbuhan sebagai obat tradisional berkembang pesat dan banyak dijadikan obat alternatif oleh sebagian masyarakat. Salah satu tumbuhan yang berpotensi sebagai obat tradisional adalah suruhan (Peperomia pellucida L. Kunth).

Berbagai penelitian sudah dilakukan dan menunjukkan bahwa tumbuhan ini memiliki aktivitas analgesik, antipiretik, antiinflamasi, hipoglikemik (Sheikh et al., 2012), antibakteri (Xu et al., 2006), antijamur (Majumunder et al., 2011), antimikroba dan antikanker (Wei et al., 2011). Nwokocha et al. (2012) menyebutkan bahwa senyawa yang terkandung pada tanaman suruhan (Peperomia pellucida L. Kunth) yaitu alkaloid dan flavonoid seperti acacetin, apigenin, isovitexin dan pellucidatin, pitosterol.

Penelitian ini bertujuan untuk mengetahui aktivitas antibakteri ekstrak etanol daun suruhan (Peperomia pellucida L. Kunth) terhadap bakteri $S$. aureus. Penelitian ini diharapkan dapat dijadikan sebagai solusi peningkatan kasus resistensi bakteri dan sebagai pengobatan alternatif penyakit infeksi kulit dan keracunan makanan yang disebabkan oleh bakteri $S$. aureus. 


\section{METODE PENELITIAN Alat dan Bahan}

Alat yang digunakan dalam penelitian ini adalah oven, ayakan nomor 60 , bejana maserasi, corong pisah, kertas saring, seperangkat alat Rotary Evaporator, gelas penyimpanan ekstrak, timbangan analitis, cawan petri, tabung reaksi, inkas, jarum ose, lampu spirtus, rak tabung reaksi, mikroskop, inkubator, dan autoklaf.

Bahan utama yang digunakan adalah daun suruhan yang diperoleh dari daerah Malang, bakteri S. aureus, etanol $70 \%$, aquadest, Brain Heart Infusion (BHI), Nutrient agar (NA), media Muller Hinton Agar (MHA), DMSO $2 \%$, larutan kristal violet (Gram A), larutan mordant (Gram B), alkohol (Gram C), dan safranin (Gram D), HCL $2 \mathrm{~N}, \mathrm{FeCL}_{3}$, serbuk $\mathrm{Mg}, \mathrm{NaCl}$, pereaksi Mayer, Wagner, dan Dragendroff.

\section{Jalannya Penelitian Pembuatan Ekstrak}

Pembuatan ekstrak daun suruhan dimulai dengan melakukan determinasi tumbuhan suruhan untuk mengetahui kebenaran dari tumbuhan yang akan digunakan. Tumbuhan suruhan yang sudah dideterminasi kemudian diambil daunnya, dibersihkan dari kotoran dan dipilih daun yang mempunyai kondisi yang baik. Selanjutnya daun suruhan seberat 10 $\mathrm{kg}$ dikeringkan dengan menggunakan oven dan ditimbang bobot keringnya. Daun suruhan yang sudah dikeringkan kemudian dihaluskan hingga membentuk serbuk. Serbuk simplisia kemudian diekstraksi menggunkan metode maserasi dengan menggunakan pelarut etanol $70 \%$, perbandingan sampel dan pelarut adalah 1:5. Maserasi dilakukan selama 5 hari dalam kondisi terlindung dari cahaya dan dilakukan pengadukkan sesekali. Endapan dipisahkan dari pelarutnya dengan cara disaring. Filtrat yang diperoleh dipekatkan dengan rotary evaporator pada suhu $40^{\circ} \mathrm{C}$ sehingga menjadi ekstrak etanol daun suruhan yang pekat. Ekstrak etanol daun suruhan dibuat menjadi 5 seri konsentrasi yaitu $100 \% \mathrm{~b} / \mathrm{v}, 80 \% \mathrm{~b} / \mathrm{v}$, $60 \% \mathrm{~b} / \mathrm{v}, 40 \% \mathrm{~b} / \mathrm{v}$ dan $20 \% \mathrm{~b} / \mathrm{v}$. Larutan pengencer yang digunakan adalah DMSO 2\%.

\section{Pembuatan Suspensi Bakteri}

Biakan murni $S$. aureus dicat Gram terlebih dahulu dan dilihat di bawah mikroskop untuk memastikan sifat Gram dari S. aureus. Pembuatan suspensi bakteri menggacu pada metode Assidqi dkk (2012) yaitu, bakteri sebanyak 1 ose diambil dari media NA yang telah diinkubasi selama 24 jam pada suhu $37^{\circ} \mathrm{C}$, kemudian dimasukkan ke dalam tabung yang berisi media $\mathrm{BHI}$, lalu diencerkan dengan $\mathrm{NaCl}$ 0,9\% sampai kerapatan bakteri sama dengan standar Mc. Farland 0,5 (10 $\mathrm{CFU} / \mathrm{ml})$.

\section{Uji Antibakteri}

Uji aktivitas antibakteri yang digunakan dalam penelitian ini adalah metode dilusi. Metode dilusi dilakukan untuk menentukan nilai Konsentrasi Hambat Minimum (KHM) dan Konsentrasi Bunuh Minimum (KBM). Penelitian ini menggunakan 5 seri konsentarsi pengenceran yakni 100\%, $80 \%$, $60 \%$, $40 \%$, dan $20 \%$, kontrol negatif (sisa pengenceran ekstrak), serta kontrol positif (suspensi bakteri).

Konsentrasi Hambat Minimum dari ekstrak daun suruhan diperoleh 
dengan cara menambahkan $0.5 \mathrm{ml}$ biakan cair bakteri $S$. aureus dengan kerapatan $10^{8} \quad \mathrm{CFU} / \mathrm{ml}$ ke dalam masing-masing tabung reaksi yang berisi $1 \mathrm{~mL}$ larutan uji dengan berbagai seri konsentrasi. Tabung reaksi tersebut diinkubasi selama 24-48 jam dalam suhu $37^{\circ} \mathrm{C}$. Pertumbuhan bakteri ditandai dengan terjadinya kekeruhan pada tabung reaksi yang berisi ekstrak etanol daun suruhan. Kekeruhan yang terjadi diamati dan dibandingkan dengan kontrol secara kasat mata.

Penentuan Konsentrasi Bunuh Minimum dilakukan dengan metode streak plate. Kultur ulang ini dilakukan dengan menggoreskan larutan pada tabung reaksi yang tetap bening setelah dilakukan perlakuan (hasil KHM) pada media MHA. Kultur diinkubasi selama 24-48 jam dalam suhu $37^{\circ} \mathrm{C}$. Konsentrasi paling rendah yang tidak menunjukkan adanya pertumbuhan koloni bakteri pada media MHA adalah KBM.

\section{HASIL DAN PEMBAHASAN Determinasi dan Pembuatan Ektrak Daun Suruhan}

Bahan utama yang digunakan dalam penelitian ini berupa daun suruhan yang diperoleh dari Malang. Determinasi terhadap sampel dilakukan di Laboratorium Morfologi dan Sistematika Tumbuhan, Fakultas Farmasi, Universitas Setia Budi. Daun suruhan seberat $10 \mathrm{~kg}$ dikeringkan kemudian dibuat serbuk. Serbuk yang diperoleh pada penelitian ini seberat 650 gr. Ekstraksi terhadap serbuk simplisia daun suruhan menggunakan metode maserasi. Serbuk kemudian diekstrak menggunakan pelarut etanol
$70 \%$ dan jumlah ekstrak yang diperoleh adalah sebesar $114 \mathrm{gr}$ dengan rendemen sebesar 17,53\%.

Ekstrak etanol daun suruhan kemudian dilakukan identifikasi kandungan senyawa. Identifikasi kandungan senyawa kimia dimasudkan untuk menetapkan kebenaran kandungan kimia yang terdapat pada daun suruhan. Pengujian meliputi kandungan senyawa alkaloid, flavonoid, saponin, dan tanin. Berikut hasil uji identifikasi kandungan senyawa pada ekstrak etanol daun suruhan (Tabel 1, Gambar 1).

Tabel 1. Hasil identifikasi kandungan senyawa kimia daun suruhan

\begin{tabular}{|c|c|c|}
\hline $\begin{array}{c}\text { Uji } \\
\text { fitokimia }\end{array}$ & $\begin{array}{c}\text { Hasil positif } \\
\text { menurut pustaka }\end{array}$ & Hasil \\
\hline \multirow{3}{*}{ Alkaloid } & $\begin{array}{l}\text { Terbentuk warna } \\
\text { jingga (pereaksi } \\
\text { Dragendroff) }\end{array}$ & + \\
\hline & $\begin{array}{l}\text { Terbentuk } \\
\text { endapan putih } \\
\text { (pereaksi Mayer) }\end{array}$ & - \\
\hline & $\begin{array}{l}\text { Terbentuk warna } \\
\text { cokelat } \\
\text { kemerahan } \\
\text { (pereaksi Wagner) }\end{array}$ & + \\
\hline Flavonoid & $\begin{array}{l}\text { Terbentuk warna } \\
\text { jingga }\end{array}$ & + \\
\hline Saponin & Terbentuk busa & + \\
\hline Tanin & $\begin{array}{l}\text { Terbentuk warna } \\
\text { biru tua atau hijau } \\
\text { kehitaman }\end{array}$ & + \\
\hline
\end{tabular}

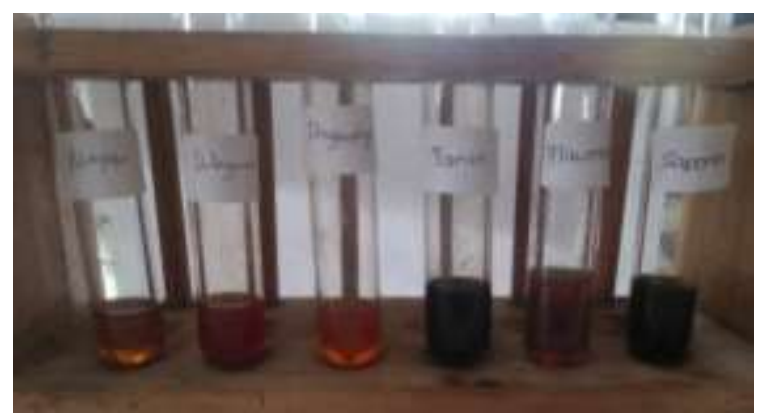

Gambar 1. Hasil identifikasi kandungan senyawa kimia daun suruhan 


\section{Uji aktivitas antibakteri ekstrak daun suruhan}

Bakteri S. aureus yang akan digunakan untuk uji dipastikan kebenarannya dengan cara pewarnaan Gram. Hasil pewarnaan menunjukkan bakteri bersifat Gram positif yang ditandai dengan warna sel bakteri ungu, berbentuk bulat bergerombol (Gambar 2).

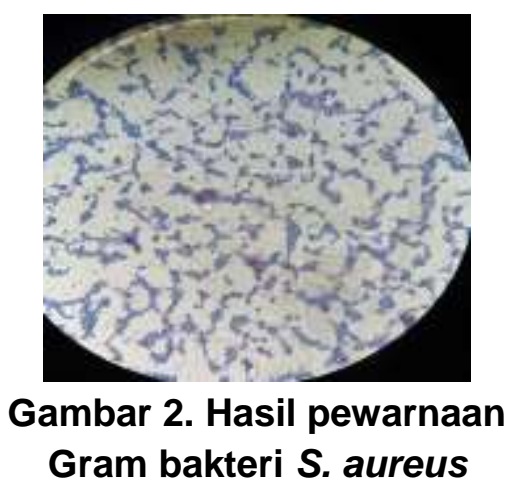

Uji aktivitas antibakteri ekstrak daun suruhan terhadap bakteri $S$. aureus dilakukan dengan menggunakan metode dilusi. Pada metode dilusi cair digunakan kontrol negatif yang berisi sisa pengenceran ekstrak, sedangkan kontrol positif berisi suspensi bakteri. Parameter Konsentrasi Hambat Minimum (KHM) dengan metode dilusi cair dapat diketahui dengan melihat adanya kekeruhan (adanya pertumbuhan bakteri) dan kejernihan (tidak adanya pertumbuhan bakteri) yang terlihat setelah inkubasi selama 24 jam.

Nilai KHM dapat ditentukan dengan cara melihat konsentrasi terkecil ekstrak daun suruhan yang masih jernih yang menunjukkan tidak adanya pertumbuhan bakteri. Hasil penelitian menunjukkan tabung reaksi pada semua seri konsentrasi tidak dapat diamati karena ekstrak terlalu pekat dan kental, sehingga diperlukan metode dilusi padat dengan menggunakan media MHA. Penentuan nilai KBM dilakukan dengan penggoresan larutan uji KHM pada media MHA, kemudian diinkubasi selama 24 jam untuk dilihat ada tidaknya pertumbuhan bakteri. Berikut ini tabel hasil penelitian uji KHM.

\section{Tabel 2. Konsentrasi Hambat Minimum (KHM) ekstrak daun suruhan terhadap bakteri S. aureus}

\begin{tabular}{cccc}
\hline \multirow{2}{*}{$\begin{array}{c}\text { Konsentra } \\
\text { si (\%) }\end{array}$} & \multicolumn{3}{c}{ Hasil } \\
\cline { 2 - 4 } & $\begin{array}{c}\text { Replik } \\
\text { asi 1 }\end{array}$ & $\begin{array}{c}\text { Replik } \\
\text { asi 2 }\end{array}$ & $\begin{array}{c}\text { Replik } \\
\text { asi 3 }\end{array}$ \\
\hline $100 \%$ & TT & TT & TT \\
\hline $80 \%$ & TT & TT & TT \\
\hline $60 \%$ & TT & TT & TT \\
\hline $40 \%$ & TT & TT & TT \\
\hline $20 \%$ & TT & TT & TT \\
\hline K+ & + & + & + \\
\hline K- & - & - & - \\
\hline
\end{tabular}

Keterangan:

$(+)=$ Terdapat pertumbuhan bakteri

$(-) \quad=$ Tidak terdapat pertumbuhan bakteri

TT $=$ Tidak terlihat

Pada Tabel 2. menunjukkan bahwa ekstrak daun suruhan pada konsentrasi $100 \%$, 80\%, 60\%, 40\%, dan $20 \%$ tidak dapat diamati dengan jelas karena warna ekstrak yang terlalu pekat yaitu hijau tua. Warna larutan yang gelap mempersulit dalam mengamati kejernihan tabung yang berisi campuran antara media $\mathrm{BHI}$, ekstrak daun suruhan dan bakteri $S$. aureus, sehingga nilai Konsentrasi 
Hambat Minimum (KHM) pada penelitian ini tidak dapat ditentukan. Dzen (2003) menyebutkan salah satu cara yang dapat dilakukan untuk menentukan nilai KHM apabila hasil ekstrak terlalu keruh yaitu dengan cara difusi cakram. Pertumbuhan bakteri terjadi pada kontrol positif yaitu tabung yang berisi suspensi bakteri, sedangkan pada kontrol negatif tidak terjadi pertumbuhan bakteri.

Larutan uji KHM ekstrak daun suruhan pada semua konsentrasi dilakukan penggoresan pada media MHA, kemudian diinkubasi selama 24 jam pada suhu $37^{\circ} \mathrm{C}$. Nilai Konsentrasi Bunuh Minimum (KBM) dapat ditentukan dengan melihat ada tidaknya pertumbuhan bakteri pada media MHA.

\section{Tabel 3. Konsentrasi Bunuh Minimum (KBM) ekstrak daun suruhan terhadap bakteri $S$. aureus}

\begin{tabular}{cccc}
\hline \multirow{2}{*}{$\begin{array}{c}\text { Konsentrasi } \\
(\%)\end{array}$} & $\begin{array}{c}\text { Replik } \\
\text { asi 1 }\end{array}$ & $\begin{array}{c}\text { Replik } \\
\text { asi 2 }\end{array}$ & $\begin{array}{c}\text { Replik } \\
\text { asi 3 }\end{array}$ \\
\cline { 2 - 4 } $100 \%$ & - & - & - \\
\hline $80 \%$ & - & - & - \\
\hline $60 \%$ & - & - & - \\
\hline $40 \%$ & - & - & - \\
\hline $20 \%$ & + & + & + \\
\hline $\mathrm{K}+$ & + & + & + \\
\hline $\mathrm{K}-$ & - & - & - \\
\hline
\end{tabular}

Keterangan:

$(+)=$ terdapat pertumbuhan bakteri

$(-)=$ tidak terdapat pertumbuhan bakteri

Hasil pengamatan menunjukkan bahwa pada konsentrasi $20 \%$ terdapat pertumbuhan bakteri $S$. aureus, sedangkan pada konsentrasi $100 \%$, $80 \%, 60 \%$, dan $40 \%$ menunjukkan tidak terlihat adanya pertumbuhan bakteri. Nilai KBM ekstrak daun suruhan terhadap bakteri $S$. aureus yang didapat adalah konsentrasi 40\%. Berikut hasil uji KBM (Tabel 3, Gambar $3)$.
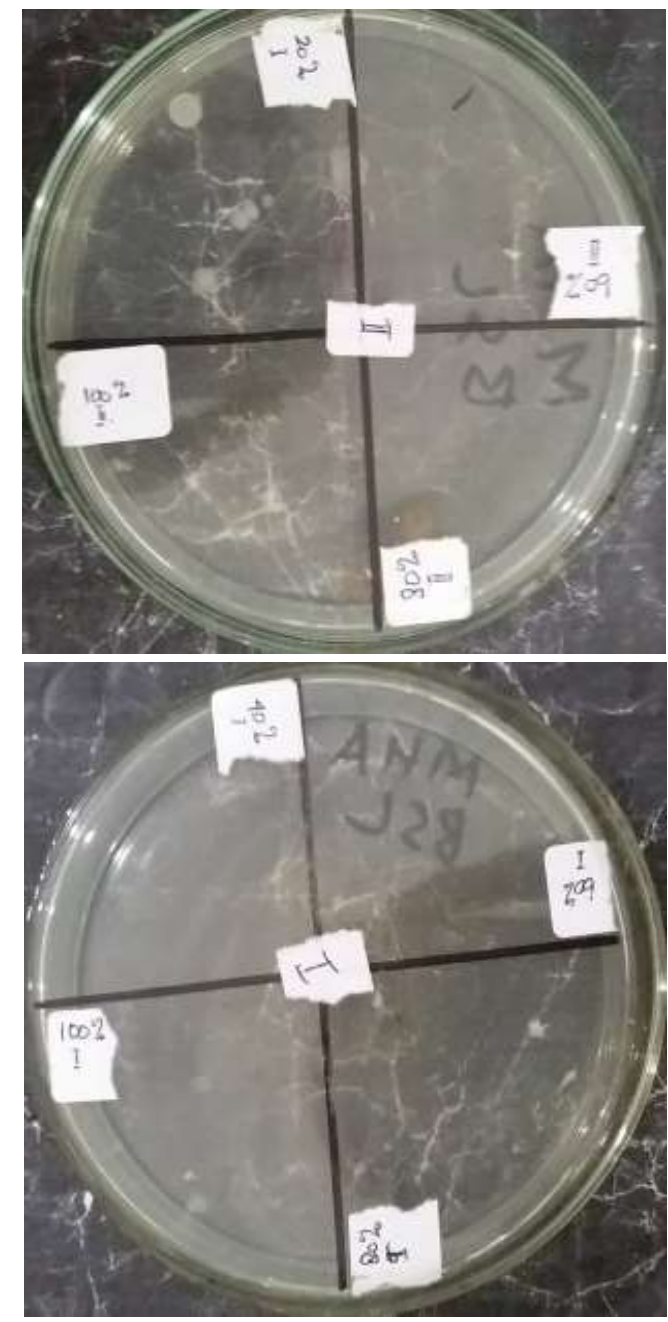

\section{Gambar 3. Hasil uji KBM ekstrak daun suruhan terhadap bakteri $S$. aureus}

Penghambatan pertumbuhan bakteri terjadi akibat adanya suatu zat yang berdampak pada fungsi membran, sintesis dinding sel, sintesis protein, dan sintesis asam nukleat bakteri (Jawetz, 2005). Aktivitas 
antibakteri daun suruhan diperkirakan karena terdapat kandungan tanin dan flavonoid pada daun suruhan (Tabel 1 , Majumder dan Kumar, 2011). Tanin memiliki aktifitas antibakteri yang berhubungan dengan kemampuannya untuk menonaktifkan adhesin dan enzim sel mikroba, serta mengganggu transport protein pada lapisan dalam sel (Ngajow et al., 2013). Monalisa et al. (2011) menyatakan flavonoid mempunyai kemampuan antibakteri yang merusak dinding sel bakteri karena berikatan dengan protein yang mengakibatkan sel bakteri lisis sehingga bakteri mati. Flavonoid juga dapat menggumpalkan protein, bersifat lipofilik, sehingga lapisan lipid membran sel bakteri akan rusak.

\section{KESIMPULAN}

Ekstrak etanol daun suruhan (Piperomia pellucida L. Kunt) memiliki aktivitas antibakteri terhadap bakteri $S$. aureus secara in vitro. Nilai konsentrasi hambat minimum (KHM) ekstrak daun suruhan terhadap bakteri $S$. aureus tidak dapat ditentukan, sedangkan nilai Konsentrasi Bunuh Minimum (KMB) ekstrak daun suruhan terhadap bakteri S. aureus adalah sebesar $40 \%$.

\section{DAFTAR PUSTAKA}

Afifurrahman, K. 2014. Pola Kepekaan Bakteri Staphylococcus aureus terhadap Antibiotik Vancomycin di RSUP Dr. Mohammad Hoesin Palembang. http://ejournal.unsri.ac.id/index. php/mks/article/viewFile/2716/p df.

Assidqi K., Wahyu T., dan Setyawati S. 2012. Potensi Ekstrak Daun
Patikan Kebo (Euphorbia hirta) sebagai Antibakteri terhadap Aeromonas hydrophila Secara In Vitro. Journal of Marine and Coastal Science. 1 (2):113-124.

Conrad, M. 2010. Staph Infection (Staphylococcus aureus). Tersedia di MedicineNet: https://www.medicinenet.com/st aph infection/article.htm

Dzen S.J., Roekistiningsih, Santoso S., Winarsih S. Bakteriologi Medik. 1st Ed. Malang: Bayumedia Publishing; 2003.

Jawetz, E., J.L. Melnick., E.A. Adelberg., G.F. Brooks., J.S. Butel., dan L.N. Ornston. 2005. Mikrobiologi Kedokteran. Edisi ke-20

(Alihbahasa:Nugroho\&R.F.Maul any).Jakarta : Penerbit Buku Kedokteran EGC. Hal 211,213,215.

Majumder P., Kumar, K. V. Arun. 2011. Establishment of Quality Parameters and Pharmacognostic Evaluation of Leaves of Peperomia pellucida (L.) Hbk. International Journal of Pharmacy and Pharmaceutical Sciences. 3 (5).

Monalisa, D., Handayani, T. dan Sukmawati, D. 2011. Uji Daya Antibakteri Ekstrak daun Tapak Liman (Elephantopus sacber L.) Terhadap Staphlococcus aureus dan Salmonella typhi. Jurnal Bioma, 9(2), 13-20.

Ngajow M, Abidjulu J, Kamu V.S. Pengaruh Antibakteri Ekstrak Kulit Batang Matoa (Pometia pinnata) terhadap Bakteri Staphylococcus aureus secara 
In vitro. Jurnal MIPA UNSRAT Online. 2013;2(2):182-132.

Nwokocha, C.R., Owu D.U., Kinlocke K., Murray J., Delgoda J. 2012. Possible Mechanism of Action of the Hypotensive Effect of Peperomia pellucida and Interactions Between Human Cytochrome P450 Enzymes. Medicinal and Aromatic Plants 1:1-5.

Sheikh H, Sikder S, Paul S.K., Hasan R.A.M., Rahaman M.M., Kundu S.P. 2013. Hipoglikemik, Antiinflamasi dan Aktivitas Analgesik Tumpangan air (L.) HBK (Piperaceae). Int J Pharm Sci Res 4: 458-63.

Utami ER. Antibiotika, Resistensi, dan Rasionalitas Terapi. 2012. Saintis 1 (1): 124-38.

Wei, L.S., W. Wee, J.Y.F. Siong, \& D.F. Syamsumir. 2011. Characterization of Anticancer, Antimicrobial, Antioxidant Properties and Chemical Compositions of Peperomia pellucida Leaf Extract. Acta Medica Iranica 49(10): 670-674.

Xu, S., Li, N., Ning, M.M., Zhou, C.H., Yang, Q.R., Wang, M.W. 2006. Bioaktif Senyawa dari Tumpangan Air. J Nat Prod. 69: 247-5.

Yuwono. 2010. Pandemi Resistensi Antimikroba: Belajar dari MRSA. Jurnal Kedokteran dan Kesehatan, 1 (42), 2837-2850. 